\title{
Sunscreen Activities of Bark Artocarpus heterophyllus against Ultraviolet Ray (Sun Protection Factor) in Lotion Formula
}

\author{
Bastian Arifin, Rosnani Nasution*, Savila Savila, Rika Ramadani, Hira Helwati, Marianne Marianne, Ulil Amna, Nurdin Saidi \\ Department of Chemistry, Faculty of Natural Sciences and Mathematics, University of Syiah Kuala, Banda Aceh, Indonesia
}

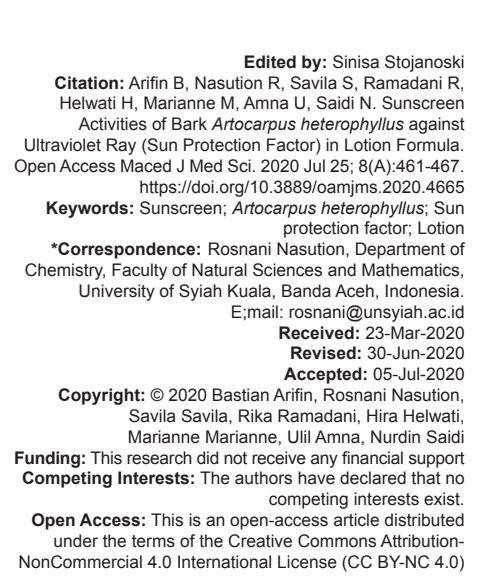

Abstract

Sunscreen lotion is used to prevent the skin from ultraviolet radiation, which can cause various diseases, such as acne, burning, redness, swelling, wrinkling, and skin cancer. Natural sunscreen lotions contain chemical compounds that have relatively long conjugated double bonds or the presence of hydroxyl groups. The result of the maceration of Artocarpus heterophyllus bark produced ethanol and methanol extracts, based on gas chromatography-mass spectrometry characterization, both extracts contained straight and cyclic chain compounds which had conjugated double bonds. The number of double-bonded compounds in ethanol extract is more than in methanol extract. Sun protection factor (SPF) value of ethanol extract lotion formula is greater than SPF value of methanol extract lotion formula, the SPF value ethanol extract lotion formula at concentration $2 ; 2.5 ; 5 ; 7.5$; and $12 \%$ were consecutive: $29.801 \pm 0.224 ; 32.797 \pm 0.161 ; 33.808 \pm 0.165 ; 34.580 \pm 0.295$; and $35.015 \pm 0.169$, (SPF value of negative control: $0.435 \pm 0.2839$ and positive control, $31 \pm 0.0284$ ). SPF value of methanol extract lotion formula for concentration 2 $2.5 ; 5 ; 7.5$; and $12 \%$ was $14.407 \pm 0.010 ; 26.549 \pm 0.476 ; 30.274 \pm 0.208 ; 32.031 \pm 0.302 ;$ and $31.942 \pm 0.324$. Each extract SPF value is higher than the SPF value of the lotion formula. The result of testing the physical properties of the lotion formula shows that the lotion type is o/w, the lotion viscosity ranges from $2450 \mathrm{cP}$ to $4780.0 \mathrm{cP}$ meet Standar Nasional Indonesia (SNI) standards. The $\mathrm{pH}$ test results ranged from 6.020 to 7.845 meets SNI. The spreading power of the lotion ranges from 4.70 to $6.75 \mathrm{~cm}$. The adhesive strength of the lotion ranges from 16 to $41 \mathrm{~s}$

\section{Introduction}

Skin is the first protector system of the human body from the external threat. However, in excess level, the system can be broken [1]. The high exposure on the external body by heavy metal [2], [3], pathogen [4], [5], and radiation [6] can impair the skin protector. In a tropical country like Indonesia, the exposure of sunlight radiation is inevitable. The sun shines throughout the year. Even in summer, it shines brightly until the temperature reaches $36^{\circ} \mathrm{C}$. This hot weather can cause skin dehydration which can have an impact on the skin that becomes dry and prone to sunburn.

Sunlight consists of various electromagnetic radiation, one of which is ultraviolet, which can excite electrons in the skin material from the ground state to the excitation state [7]. This induces the formation of abnormal tissue and ravages a skin protection system. There are several diseases that are caused by skin protection disorder that are eczema [8], rash, dermatitis [9], [10], skin cancer [11], and so on. To avoid the diseases caused by ultraviolet exposure, the skin needs to have external protection, sunscreen.

Sunscreen is one product that has the ability to absorb or reflect sunlight and protect the body from sunburn [12]. Lotion can moisturize the skin, prevent scaly, and dull skin also prevent the danger of ultraviolet (UV) A and UV B for skin health. Because of the sensitivity, the active compound to use in the product that is applied in skin media should be natural. The natural product offers a good choice. It has no side effects, safer [12], and green chemistry [13]. Moreover, the natural product also provides many medicinal benefit such as antibacterial [14], [15], [16], antimicrobial [17], antibiofilm [18], antipyretics [19], dental therapeutic treatment [20], wound healing [21], and antioxidant [22]. The use of synthetic active ingredients, in addition to being able to stimulate the skin resulting in irritation, can cause other things, including disruption of the nasal mucous membranes, cancer, nerve cells, and other disorders [22].

In sunscreen purposes, antioxidant ability plays an important role in the photoprotective activity. The active compound needs to have conjugated double bonds or hydroxyl groups. One of the plants containing these characters is Artocarpus heterophyllus plants [23]. A. heterophyllus has several pharmaceutical values. The leaves are traditionally used as medicine for wounds. The stem is used to cure anemia, asthma, dermatitis, diarrhea, cough, and as expectorants [24]. The roots are used to treat skin diseases and asthma, fever, diarrhea [25], fungal infections, and skin disorders [26]. 
The ethanol extracts of $A$. heterophyllus showed the antioxidant activity to capture free radicals with inhibition concentration $50 \%\left(\mathrm{IC}_{50}\right.$ is $\left.410 \mu \mathrm{g} / \mathrm{ml}\right)$. This provides a photoprotective ability of a sunscreen to prevent disease. The extract also showed a tyrosinase inhibitor activity. This finding provides an additional benefit as a skin lightening agent [27], [28], [29], [30].

There are several sunscreen products found in the market, which are lotion, gel, spray, foam, and stick, but the lotion form is the best one. This form can also be functioned as a skin moisturizer. Furthermore, it is applicable because it is not dense [31]. In this research, $A$. heterophyllus bark extract was used as an active material to make sunscreen. The compound in the extract was identified by gas chromatography-mass spectrometry (GC/MS). The sun protection factor (SPF) determination was used as an indicator of sunscreen ability.

\section{Materials and Methods}

\section{Plant material}

A. heterophyllus bark taken in Lhoknga Aceh Besar District, Indonesia. Lotion-making material (cetyl alcohol, stearic acid, lanolin, glycerin, methylparabens, triethanolamines, and aqua distillates), n-hexane, ethanol $96 \%$, and methanol, reagents for phytochemicals (Liebermann-Burchard, Dragendorff, etc.), purchased from the Rudang store in Medan, North Sumatra.

\section{Spectroscopic investigation}

Characterized of the extract was measured using a Shimadzu of GC-MS QP 2010 Ultra, electric balance (Mettler Toledo, Japan), spectrophotometer of 1240 Shimadzu UV-VIS mini, rotary evaporator, pH meter 710 A Thermo electron Orion, Thermo scientific HAAKE Viscotester C Viscometer, scatter power test equipment, and glassware.

\section{Phytochemical screening}

The method used for testing the phytochemicals can be found in phytochemical methods, a guide to modern techniques of plant analysis [31].

\section{Extraction of ethanol extract and methanol} extract from $A$. heterophyllus stem bark

The amount of $1725 \mathrm{~kg}$ of dry A. heterophyllus bark samples was mashed and macerated with solvents. This research uses two solvents, namely, ethanol and methanol, ethanol solvent will extract the semipolar compounds, while methanol solvent extracts polar compounds. Maceration is done for $3 \times 24 \mathrm{~h}$, then the extract is filtered and concentrated using a rotary evaporator. The results of the maceration of A. heterophyllus bark using ethanol solvent obtained ethanol extract as much as $27 \mathrm{~g}(1.56 \%)$ and methanol extract as much as $12 \mathrm{~g}(0.69 \%)$. The ethanol extract and methanol extract were characterized by GC-MS, the sunscreen activity was tested by measuring the SPF, then the physical properties were tested.

\section{Making formula lotion from ethanol extract and methanol extract of $A$. heterophyllus bark}

Ethanol extract lotion formula and methanol extract lotion formula, from $A$. heterophyllus bark extract with cetyl alcohol, stearic acid, lanolin, glycerin, triethanolamine, methylparaben, and aqua ad 100, are in Table 1.

Table 1: The formula of lotion preparation (with modification) [32], [33]

\begin{tabular}{lllllll}
\hline No & Material & \multicolumn{7}{l}{ Composition $(\%)$} \\
\hline I & Cetyl alcohol & 0.5 & 0.5 & 0.5 & 0.5 & 0.5 \\
& Stearic acid & 3 & 3 & 3 & 3 & 3 \\
& Lanolin & 1 & 1 & 1 & 1 & 1 \\
II & Artocarpus heterophyllus stem bark extract & 2 & 2,5 & 5 & 7,5 & 12 \\
& Glycerin & 2 & 2 & 2 & 2 & 2 \\
III & Methylparaben & 0.1 & 0.1 & 0.1 & 0.1 & 0.1 \\
& Triethanolamine & 0.75 & 0.75 & 0.75 & 0.75 & 0.75 \\
& Aquades & 90.65 & 90.15 & 87.65 & 85.5 & 80.65 \\
\hline
\end{tabular}

Weighed all the necessary ingredients, part (I, from Table 1), materials are inserted into a porcelain cup and is melted over a water bath to a temperature of $70^{\circ} \mathrm{C}$. Part (III, from Table 1) is dissolved in hot Aqua. Then, part (III) is inserted in porcelain in a hot state, then added part (I) into section (III) with constant stirring until the temperature drops. At $45^{\circ} \mathrm{C}$ added ethanol and methanol extract with concentration: $2 ; 2,5 ; 5 ; 7.5$; and $12 \%$ [34] that has been mixed with glycerin (II, from Table 1) while stirring until homogeneous. It is then fed into the appropriate container [35].

\section{Measurement of SPF value}

The method for the absorption of sunscreen agents is determined based on spectrophotometric analysis [36]. A lotion sample weighing $0.5 \mathrm{~g}$ is dissolved in $25 \mathrm{~mL} 96 \%$ ethanol $(20,000 \mathrm{ppm})$. The absorbance of samples was measured with a UV spectrophotometer every $5 \mathrm{~nm}$ over a wavelength range of $290 \mathrm{~nm}-320$ $\mathrm{nm}$ with $96 \%$ ethanol as a blank. Calculation of SPF values according to using the following equation [37]. The result of calculation SPF values showed in Table 2.

Table 2: Relationship between erythemogenic effect and radiation intensity at each wavelength

\begin{tabular}{ll}
\hline Wavelength $(\mathrm{nm})$ & $\mathrm{EE} \times \mathrm{I}$ \\
\hline 290 & 0.0150 \\
295 & 0.0817 \\
300 & 0.2874 \\
305 & 0.3278 \\
310 & 0.1864 \\
315 & 0.0839 \\
320 & 0.0180 \\
Total & 1 \\
\hline
\end{tabular}




$$
\mathrm{SPF}=\mathrm{CF} \sum_{290}^{320} \mathrm{EE}(\lambda) \times \mathrm{I}(\lambda) \times \mathrm{A}(\lambda)
$$

Where: Erythema Effectiveness (EE) erythemal effect spectrum; I - solar intensity spectrum; Abs - absorbance of sunscreen product; CF - correction factor (=10). The values of EE $\times$ I are constants [36].

\section{Testing the physical properties of the lotion}

Tests for physical properties of lotions include tests for lotion type, spreadability, stickiness viscosity, and $\mathrm{pH}$.

\section{Lotion type test}

The type of emulsion of a pharmaceutical preparation is classified as o/w (oil in water) if the preparation has an electrical conductivity marked by the movement of the ampere meter needle which has a deviation while the preparation which does not provide a deviation of the needle in the ampere meter and does not produce an electric current is classified into type emulsion o/w [38].

\section{pH test}

The $\mathrm{pH}$ test of the lotion was carried out using a $\mathrm{pH}$ meter that had been calibrated with an equimolar buffer of $\mathrm{pH} 7$ and a potassium hydroxy phthalate buffer of $\mathrm{pH} 4$. The electrodes were dipped in preparations that had been diluted with distilled water (1 part lotion diluted with 9 parts distilled water), indicated by the $\mathrm{pH}$ meter. The $\mathrm{pH}$ measurement of the lotion is carried out using a $\mathrm{pH}$ meter $710 \mathrm{~A}+$ Thermo electron corporation Orion.

\section{Viscosity test}

The value of viscosity will affect the spread of formulations on the skin [39]. The lotion viscosity was measured using a Thermo Scientific HAAKE Viscotester Viscometer C.

\section{Scattering test}

Lotion weighing $0.5 \mathrm{~g}$ is placed in the middle of a large round glass. On top of the lotion is placed another round glass and ballast so that the weight of the round glass and ballast is $100 \mathrm{~g}$, allowed to stand for $1 \mathrm{~min}$, then note the distribution diameter.

\section{Adhesion test}

A total of $0.2 \mathrm{~g}$ of lotion formulation is placed on a glass plate preparation. The other glass plate was pressed together on the glass that had been given lotion until it was fused and placed with a weight of $50 \mathrm{~g}$ for $5 \min$ [40].

\section{Results and Discussion}

\section{Phytochemical testing}

Phytochemical testing is carried out on the presence of triterpenoids, steroids, flavonoids, alkaloids, and saponins. The phytochemical test results of ethanol extract and methanol extract can be seen in Table 3.

Table 3: Phytochemical test results of fresh stem bark, ethanol extract, and methanol extract of bark Artocarpus heterophyllus

\begin{tabular}{|c|c|c|c|c|c|}
\hline $\begin{array}{l}\text { Secondary } \\
\text { metabolites }\end{array}$ & Testing method & $\begin{array}{l}\begin{array}{l}\text { Fresh } \\
\text { bark }\end{array} \\
\end{array}$ & $\begin{array}{l}\text { Methanol } \\
\text { extract }\end{array}$ & $\begin{array}{l}\text { Ethanol } \\
\text { extract }\end{array}$ & Characteristics \\
\hline \multirow[t]{3}{*}{ Alkaloids } & Mayer's reagent & + & + & + & Red sediment \\
\hline & Wagner's reagent & + & + & + & $\begin{array}{l}\text { Chocolate } \\
\text { deposition } \\
\text { brown sediment }\end{array}$ \\
\hline & Dragendorff reagents & + & + & + & Sediment \\
\hline Steroids & $\begin{array}{l}\text { Liebermann- } \\
\text { Burchard reagent }\end{array}$ & - & - & - & Red \\
\hline Triterpenoid & $\begin{array}{l}\text { Liebermann- } \\
\text { Burchard reagent }\end{array}$ & + & + & + & Red \\
\hline Saponin & Shuffle & + & + & + & Stable foam $\pm 30 \mathrm{~s}$ \\
\hline Phenolic & $\mathrm{FeCl}_{3}$ reagent & + & + & + & Black \\
\hline Flavonoids & $\begin{array}{l}0.5 \mathrm{~g} \text { of mg powders } \\
\text { and } \mathrm{HCl}\end{array}$ & + & + & + & Brownish-yellow \\
\hline
\end{tabular}

Based on Table 3, fresh bark, ethanol extract, and methanol extract of $A$. heterophyllus stem bark, positively contain secondary metabolites of alkaloids, triterpenoids, flavonoids, and saponins, and do not contain steroids.

The existence of secondary metabolites of alkaloids, triterpenoids, flavonoids, and saponins in ethanol and methanol extracts because these secondary metabolites can dissolve into the two solvents. The presence of compounds with conjugated double bonds such as flavonoids shows a reddish color with $\mathrm{Mg}$ powder and $\mathrm{HCl}$ solvents [41]. This compound can absorb ultraviolet radiation. According to the literature, $A$. heterophyllus contains many flavonoids or conjugated double-bonded compounds [42].

\section{The compound in the ethanol and} methanol extract of $A$. heterophyllus bark

Chemical compounds were being analyzed with the NISTI Lab. 4 Library in MS. Chemical compounds contained in ethanol extract of $A$. heterophyllus with the composition as shown in Table 4;

The compound in the ethanol extract of A. heterophyllus stem bark contains compounds that have double bonds such as phenol, 3,5-bis (1,1- dimethylethyl) -; 2- (4-Ethyl-2-acetoxy-5-methoxyphenyl) acetic acid, methyl ester; retinal; phthalic acid monooctyl ester; methyl 7,8-octadecadienoate; methyl hexadec-9-enoate; 9-Hexadecenoic acid, methyl ester, (Z)-; Methyl 10-trans, 
12-cis-octadecadienoate -; 9-Octadecenoic acid, methyl ester, (E)-; phytol; 9,12-Octadecadienoic acid (Z, Z) -; cholesterol margarate; gamma.-Linolenic acid, methyl ester; Cholest-22-ene-21-ol, 3,5-dehydro-6-methoxy-, pivalate; hexadecanoic acid, 1-(hydroxymethyl)-1,2ethanediyl ester; and Bis(2-ethylhexyl) phthalate.

Table 4: Chemical compounds contained in ethanolic extract of Artocarpus heterophyllus stem bark (from gas chromatographymass spectrometry)

\begin{tabular}{llll}
\hline No. & Area & Similarity & Name \\
\hline 1 & 0.24 & 85 & Phenol, 3,5-bis(1,1-dimethylethyl) \\
2 & 0.33 & 73 & 2-(4-Ethyl-2-acetoxy-5-methoxyphenyl)acetic acid, methyl ester \\
3 & 1.03 & 76 & Retinal \\
4 & 0.60 & 82 & Phthalic acid, monooctyl ester \\
5 & 0.86 & 82 & Methyl 7,8-octadecadienoate \\
6 & $0.43+0.85$ & 84 & Methyl hexadec-9-enoate \\
7 & 0.33 & 82 & 9-Hexadecenoic acid, methyl ester, (Z)- \\
8 & 17.73 & 93 & Methyl 10-trans,12-cis-octadecadienoate \\
9 & 14.00 & 91 & 9-Octadecenoic acid, methyl ester, (E)- \\
10 & 1.25 & 89 & Phytol \\
11 & 4.48 & 90 & 9,12-Octadecadienoic acid (Z,Z)- \\
12 & 8.94 & 77 & Cholesterol margarate \\
13 & 0.68 & 78 & gamma.-Linolenic acid, methyl ester \\
14 & 1.74 & 71 & Cholest-22-ene-21-ol, 3,5-dehydro-6-methoxy-, pivalate \\
15 & 0.63 & 76 & Hexadecanoic acid, 1-(hydroxymethyl)-1,2-ethanediyl ester \\
16 & 2.14 & 94 & Bis(2-ethylhexyl) phthalate \\
\hline
\end{tabular}

These compounds with double bonds can function to reduce the energy of the sun on the object if the object is coated with these compounds [7].

Chemical compounds in methanol extracts of the bark of $A$. heterophyllus with the composition which is analyzed with the NIST Willey Library in MS, as shown in Table 5, are obtained.

Table 5: The chemical compounds contained in methanol extracts of the bark of Artocarpus heterophyllus (from gas chromatography-mass spectrometry)

\begin{tabular}{llll}
\hline No. & Area & Similarity & Name \\
\hline 1 & 0.60 & 89 & Phthalic acid, butyl undecyl ester \\
2 & 0.46 & 83 & 6,9-Octadecadienoic acid, methyl ester \\
3 & 0.38 & 82 & 6-Octadecenoic acid, methyl ester, (Z)- \\
4 & 1.40 & 77 & Phthalic acid, butyl 2-(2-nitrophenyl)ethyl ester \\
5 & 1.975 .219 .82 & 84 & Cholest-5-en-3-ol (3.beta.)-, carbonochloridate \\
6 & 3.72 & 77 & .beta.-Sitosterol acetate \\
7 & 11.87 & 94 & Methyl 10-trans, 12-cis-octadecadienoate \\
8 & 14.69 & 92 & 9-Octadecenoic acid, methyl ester, (E)- \\
9 & 0.72 & 90 & Phytol \\
10 & 0.72 & 84 & 9,12-Octadecadienoic acid (Z,Z)- \\
11 & 2.67 & 92 & Oleic Acid \\
12 & 1.37 & 92 & Bis(2-ethylhexyl) phthalate \\
\hline
\end{tabular}

The methanol extract of $A$. heterophyllus stem bark contains both straight and cyclic chain compounds, compounds that are thought to function as sunscreens are chemical compounds that have conjugated double bonds. In the methanol extract of $A$. heterophyllus, there are several compounds that have isolated and conjugated double bonds, the compounds are as follows: Phthalic acid, butyl undecyl ester. 6,9-Octadecadienoic acid, methyl ester; 6-Octadecenoic acid, methyl ester, (Z)-; phthalic acid, butyl 2-(2-nitrophenyl)ethyl ester; Cholest-5-en-3-ol (3.beta.)-, carbonochloridate; beta.-Sitosterol acetate; Methyl 10-trans,12-cisoctadecadienoate; 9-Octadecenoic acid, methyl ester, (E)-; phytol; 9,12-Octadecadienoic acid (Z,Z)-; oleic acid; and Bis(2-ethylhexyl) phthalate.

These compounds have a double bond that can function as a protective material for the human body from daylight because the double bonds (especially conjugated) can reduce the ultraviolet energy that reaches the surface of the skin coated with these compounds.

\section{Test results for the measurement of SPF} value of ethanol extract and methanol extract from A. heterophyllus bark

Sunscreen is one of the cosmetic preparations that can be used to help the body's defense mechanism from UV radiation, UV radiation which can cause reactions to the skin, including acne, burning, redness, swelling, wrinkling, etc., [43]. The efficacy of sunscreen is usually expressed by the SPF, which is defined, as the UV energy needed to produce a minimum erythema dose on protected skin, divided by the UV energy needed to produce MED on non-skin protected. A minimal erythemal dose (MED) is defined as the lowest time interval or a dose of UV irradiation sufficient to produce minimal and clear erythema on unprotected skin [43], [44]. The higher the SPF, the more effective the product is in preventing sunburn.

$$
\begin{aligned}
& \text { Minimalery the } \\
& \mathrm{SPF}=\frac{\text { madoseinsun screen }- \text { protected skin }}{\text { Minimalery the }} \\
& \text { madoseinnonsun screen - protected skin }
\end{aligned}
$$

In-vitro approaches are generally of two types: (1) Measurement of absorption or transmission of UV radiation through sunscreen product films on quartz plates or membranes and (2) methods in which the characteristics of sunscreen absorption are determined based on spectrophotometric analysis [36] A very simple mathematical equation for estimating solar protection factors by in-vitro methods using UV spectrophotometry has been developed by Mansur et al. [37]. The main advantage of in vitro testing is that it is a fast, objective, and cost-effective methodology. In vitro testing can be used as a formulation material to identify new compounds, optimize existing formulas and as an initial formula before in vivo testing in humans.

SPF test results of extracts and lotions from ethanol extract and methanol extract of $A$. heterophyllus bark with a concentration of $2 ; 2.5 ; 5 ; 7.5$; and $12 \%$ are in the following Table 6.

\begin{tabular}{|c|c|c|c|c|}
\hline \multirow{2}{*}{$\begin{array}{l}\text { Concentration } \\
(\%)\end{array}$} & \multicolumn{2}{|l|}{ SPF of extract } & \multicolumn{2}{|c|}{ SPF formula lotion } \\
\hline & Ethanol & Methanol & Ethanol & Methanol \\
\hline 2 & $36.276 \pm 0.657$ & $19.312 \pm 0.029$ & $29.801 \pm 0.224$ & $14.407 \pm 0.010$ \\
\hline 2,5 & $37.472 \pm 0.074$ & $29.990 \pm 0.344$ & $32.797 \pm 0.161$ & $26.549 \pm 0.476$ \\
\hline 5 & $37.806 \pm 0.357$ & $31.114 \pm 0.565$ & $33.808 \pm 0.165$ & $30.274 \pm .208$ \\
\hline 7.5 & $38.023 \pm 0.641$ & $31.304 \pm 0.329$ & $34.580 \pm 0.295$ & $32.031 \pm 0.302$ \\
\hline 12 & $39.839 \pm 0.162$ & $33.156 \pm 0.102$ & $35.015 \pm 0.169$ & $31.942 \pm 0.324$ \\
\hline
\end{tabular}

Table 6: SPF value of extract and lotion formula from ethanol extract and methanol extract of Artocarpus heterophyllus bark

A comparison of the SPF value of the extract and lotion of ethanol extract and methanol extract above can be illustrated as in Figure 1. 
Based on Table 6, (Figure 1), the SPF value of ethanol extract and its lotion is relatively higher than the SPF value of methanol extract and its lotion. This is due to the amount of conjugated double compound in ethanol extract is greater than that in methanol extract.

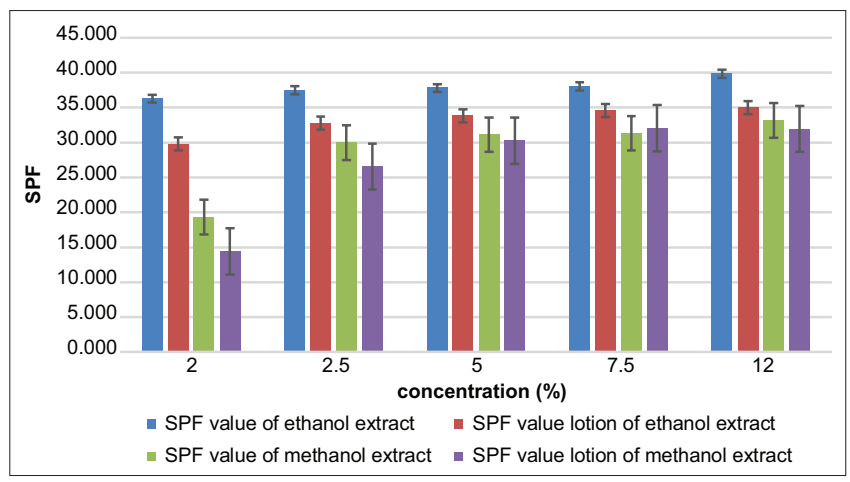

Figure 1: Comparison of the sun protection factor (SPF) value of the extract and the SPF value of the ethanol extract lotion formula and the methanol extract lotion formula

Compounds that have conjugated double bonds have the power to reduce UV energy that effects of the human body, the existence of long conjugated double bonds causes the formation of new orbitals, which can reduce UV energy to regions to longer wavelengths (to visible or infrared areas), so there is no formation of free radicals. Another mechanism is to capture free radicals that are formed, so they become neutral.

The difference in SPF value also occurs in each extract and its lotion, the SPF value of ethanol extract is greater than the SPF value of the ethanol extract lotion formula, as well as the SPF value of methanol extract is greater than the SPF of methanol extract lotion formulation. This is due to the extract containing active compounds with large concentrations that function as sunscreen, whereas the lotion has decreased the concentration of active compounds, due to dilution by lotion media.

\section{Testing of physical properties of ethanol extract lotion and methanol extract lotion}

The results of the determination of the type of emulsion of lotion formulation of ethanol extract and methanol extract showed that the lotion type is $\mathrm{o} / \mathrm{w}$, indicated by the deviation of the ampere meter needle which indicates the electrical conductivity of the lotion formulation. This type of emulsion has many advantages, including being easily rinsed with water and not sticky when used.

It is very important to measure the viscosity of lotion formulation; this is useful to see the level of viscosity of lotion formulations. The lotion viscosity value can be influenced by substances added to the lotion formulation. The value of viscosity will affect the spread of formulations on the skin [39]. The lotion formulation viscosity was measured every week for 1 month of storage, the viscosity value of methanol extract lotion and ethanol extract lotion ranged from
$2450 \mathrm{cP}$ to $4780.0 \mathrm{cP}$ (the measurement results of the formulation viscosity value of $2-12 \%$ had met the semisolid preparation standard based on (Standar Nasional Indonesia, SNI, Indonesian National Standards) 16-4399-1996 which is in the range of values between 2000 and 50,000 cP [45].

The $\mathrm{pH}$ of lotion testing is done every week for 1 month of storage. The results of $\mathrm{pH}$ testing of both ethanol extract lotion and methanol extract lotion ranged from 6.020 to 7.845 , indicating the $\mathrm{pH}$ of the lotion is still acceptable, according to SNI 16-4399-1996 where the lotion that can be used for the skin is a lotion that has a $\mathrm{pH}$ range of 4.5-8.0 [45].

The spread testing of lotion formulation can be used as a benchmark to see the spread formulation on the skin. The spreading power of the lotion of ethanol and methanol extract ranges from 4.70 to $6.75 \mathrm{~cm}$. According to research that has been done by Zulkarnain et.al. [46], semi-solid preparations that are comfortable when used to the skin are formulations which have a dispersion diameter ranging from $5-7 \mathrm{~cm}$ or equivalent to $19.6-38.46 \mathrm{~cm}^{2}$. The sample which has a spreading capacity below $5 \mathrm{~cm}$ is a formulation of $12 \%$ ethanol extract lotion at weeks 2,3 , and 4 .

The lotion formulation adhesion test was carried out to see the length of time of the formulation attached to the skin. A good formulation is one that has not too low and not too high adhesion. The adhesion of ethanol extract ranged from 16 to $23 \mathrm{~s}$ for lotion methanol extract ranged from 16 to $41 \mathrm{~s}$. Hence, this lotion qualifies because it has an adhesion of more than $4 \mathrm{~s}$ [46].

\section{Conclusions}

Ethanol and methanol extracts can be processed into sunscreen lotions that have an SPF value in the ultracategory. The SPF value of ethanol extract lotion is relatively higher than the SPF value of methanol extract lotion. The SPF value of extract of each sample is higher than the SPF value of lotion for each ethanol extract and methanol extract.

Methanol and ethanol extracts contain compounds that are conjugated in double conjugation, but ethanol extract contains more of these compounds than methanol extracts.

The SPF lotion value of ethanolic extract of bark of $A$. heterophyllus at concentrations, 2, 2.5, 5 , 7.5, and $12 \%$ was: $29.801 \pm 0.224 ; 32.797 \pm 0.161$; $33.808 \pm 0.165 ; 34.580 \pm 0.295$; and $35.015 \pm 0.169$, while the SPF value of negative control was: 0.435 \pm 0.2839 ; and positive control, $31 \pm 0.0284$, and the value of SPF of the methanol extract lotion was 14.407 $\pm 0.010 ; 26.549 \pm 0.476 ; 30.274 \pm 0.208 ; 32.031 \pm$ 0.302 ; and $31.942 \pm 0.324$. 
The results of testing the physical properties of the lotion showed that the lotion type is $\mathrm{m} / \mathrm{a}$, lotion viscosity ranges from $2450 \mathrm{cP}$ to $4780.0 \mathrm{cP}$. Test results for $\mathrm{pH}$ ranged from 6.020 to 7.845 . The spreading power of the lotion ranged from 4.70 to $6.75 \mathrm{~cm}$, the stickiness of the lotion ranged from 16 to $23 \mathrm{~s}$. Generally speaking, the physical properties of methanol extract lotion and ethanol extract lotion are in accordance with SNI.

\section{Acknowledgments}

The authors would like to thank the Syiah Kuala University, Ministry of Research, Technology and Higher Education in accordance with the Letter of Appointment Research of Professor, Fiscal Year 2019.

\section{References}

1. King A, Balaji S, Keswani SG. Biology and function of fetal and pediatric skin. Facial Plast Surg Clin North Am. 2013;21(1):1-6. PMid:23369584

2. Suhartono E, Thalib I, Aflanie I, Noor Z, Idroes R. Study of interaction between cadmium and bovine serum albumin with UV-vis spectrocopy approach. IOP Conf Ser Mater Sci Eng. 2018;350(1):12008. https://doi. org/10.1088/1757-899x/350/1/012008

3. Suhartono E, Noor Z, Edyson, Budianto WY, Idroes R. Effect of chronic lead exposure on bone using ATR-FTIR spectroscopy. AIP Conf Proc. 2019;2108(1):20025.

4. Satoh K, Ooe K, Nagayama H, Makimura K. Prototheca cutis sp. nov., a newly discovered pathogen of protothecosis isolated from inflamed human skin. Int J Syst Evol Microbiol. 2010;60(5):1236-40. https://doi.org/10.1099/ijs.0.016402-0 PMid:19666796

5. Rahmad R, Earlia $\mathrm{N}$, Nabila $\mathrm{C}$, Inayati I, Amin $\mathrm{M}$, Prakoeswa CR, et al. Antibacterial cream formulation of ethanolic Pliek $U$ extracts and ethanolic residue hexane Pliek U extracts against Staphylococcus aureus. IOP Conf Ser Mater Sci Eng. 2019;523:12011. https://doi. org/10.1088/1757-899x/523/1/012011

6. Polefka TG, Meyer TA, Agin PP, Bianchini RJ. Effects of solar radiation on the skin. J Cosmet Dermatol. 2012;11(2):134-43. https://doi.org/10.1111/j.1473-2165.2012.00614.x PMid:22672278

7. Silverstein RM, Morrill TC. Spectrometric Identification of Organic Compounds. $5^{\text {th }}$ ed. New York: Wiley; 1991.

8. Shaw TE, Currie GP, Koudelka CW, Simpson EL. Eczema prevalence in the United States: Data from the 2003 national survey of children's health. J Invest Dermatol. 2011;131(1):67-73. https://doi.org/10.1038/jid.2010.251 PMid:20739951

9. Earlia N, Rahmad R, Amin M, Prakoeswa C, Khairan K, Idroes R. The potential effect of fatty acids from Pliek $U$ on epidermal fatty acid binding protein: Chromatography and bioinformatic studies. Sains Malaysiana. 2019;48(5):1019-24. https://doi. org/10.17576/jsm-2019-4805-10

10. Suhendra R. A Novel Approach to Multi-class Atopic
Dermatitis Disease Severity Scoring Using Multi-class SVM. Indonesia: IEEE Cybern; 2019. https://doi.org/10.1109/ cyberneticscom.2019.8875693

11. Diepgen TL, Brandenburg S, Aberer W, Bauer A, Drexler H, Fartasch $\mathrm{M}$, et al. Skin cancer induced by natural UV-radiation as an occupational disease-requirements for its notification and recognition. J Dtsch Dermatol Ges. 2014;12(12):1102-6. https://doi.org/10.1111/ddg.12537 PMid:25482691

12. Goswami PK, Samant M, Srivastava R. Natural sunscreen agents: A review. Sch Acad J Pharm. 2013;2(6):458-63.

13. Paristiowati $M$, Moersilah $M$, Stephanie $M M$, Zulmanelis $Z$, Idroes R, Puspita RA. Rosa sp and Hibiscus sabdariffa L extract in ethanol fraction as acid base indicator: Application of green chemistry in education. J Phys Conf Ser. 2019;1402(5):55041. https://doi.org/10.1088/1742-6596/1402/5/055041

14. Nuraskin CA, Marlina, Idroes R, Soraya C, Djufri. Activities inhibition methanol extract Laban Leaf (Vitex pinnata) on growth of Bacteria S. mutans Atcc 31987. IOP Conf Ser Mater Sci Eng. 2019;523:1-5. https://doi.org/10.1088/1757-899x/523/1/012008

15. Tallei TE, Linelejan YT, Umboh SD, Adam AA, Muslem, Idroes R. Endophytic Bacteria isolated from the leaf of langusei (Ficus minahassae Tesym. and De Vr.) and their antibacterial activities. IOP Conf Ser Mater Sci Eng 2020;796:012047. https://doi. org/10.1088/1757-899x/796/1/012047

16. Idroes R, Yusuf M, Saiful S, Alatas M, Subhan S, Lala A, et al. Geochemistry exploration and geothermometry application in the North Zone of Seulawah Agam, Aceh Besar district, Indonesia. Energies. 2019;12(23):4442.

17. Estevam E, Griffin S, Nasim J, Zieliński D, Aszyk J, Osowicka M, et al. Inspired by nature: The use of plant-derived substrate/enzyme combinations to generate antimicrobial activity in situ. Nat Prod Commun. 2015;10(10):1733-8. https://doi.org/10.1177/1934578x1501001025 PMid:26669114

18. Pratiwi SU, Lagendijk EL, de Weert S, Idroes R, Hertiani T, Van den Hondel C. Effect of Cinnamomum burmannii Nees ex BI. and massoia aromatica becc. Essential oils on planktonic growth and biofilm formation of Pseudomonas aeruginosa and Staphylococcus aureus in vitro. Int J Appl Res Nat Prod. 2015;8(2):1-13. https://doi.org/10.1055/s-0036-1596813

19. Tallei TE, Pelealu JJ, Pollo HN, Pollo GA, Adam AA, Effendi $Y$, et al. Ethnobotanical dataset on local edible fruits in North Sulawesi, Indonesia. Data Brief. 2019;27:104681. https://doi.org/10.1016/j.dib.2019.104681 PMid:31720333

20. Ningsih DS, Idroes R, Bachtiar BM, Khairan. The potential of five therapeutic medicinal herbs for dental treatment : A review. IOP Conf Ser Mater Sci Eng. 2019;523(1):12009. https://doi. org/10.1088/1757-899x/523/1/012009

21. Earlia N, Muslem, Suhendra R, Amin M, Prakoeswa $C R$, Khairan, et al. GC/MS analysis of fatty acids on Pliek $U$ oil and its pharmacological study by molecular docking to filaggrin as drug candidate in atopic dermatitis treatment. ScientificWorldJournal. 2019;2019:8605743. https://doi.org/10.1155/2019/8605743 PMid:31780876

22. Suhartono $E$, Setiawan $B$, Santosa $P B$, Idroes $R$, Indrawan MS Estimation of leaf antioxidant activity using image processing. J Phys Conf Ser. 2019;2019:12057. https://doi. org/10.1088/1742-6596/1374/1/012057

23. Peng SD, Lin LJ, Ouyang LJ, Zhu BQ, Yuan $Y$, Jing $W$, et al Comparative analysis of volatile compounds between jackfruit (Artocarpus heterophyllus L.) peel and its pulp. Adv Mater Res. 2013;2013:1413-8. https://doi.org/10.4028/www.scientific.net/ amr.781-784.1413

24. Balbach A. In: Missionaria E, editor. As Frutas Na Medicina Natural. Sao Paulo: Vida Plena; 1992. 
25. ICUC. International Centre for Underutilized Crops Report. United Kingdom: ICUC; 2003.

26. Salguero CP, Herbal AT. Traditional Recipes for Health and Harmony. United Kingdom: Findhorn Press; 2003.

27. Likhitwitayawuid K, Chaiwiriya S, Sritularak B Lipipun V. Antiherpetic flavones from the heartwood of Artocarpus gomezianus. Chem Biodivers. 2006;3(10):1138-43. https://doi.org/10.1002/chin.200710218 PMid: 17193228

28. Arung ET, Shimizu K, Kondo R. Inhibitory effect of isoprenoid-substituted flavonoids isolated from Artocarpus heterophyllus on melanin biosynthesis. Planta Med. 2006;72(9):847-50. https://doi.org/10.1055/s-2006-931606 PMid: 16732541

29. Donsing P, Limpeanchob N, Viyoch J. Evaluation of the effect of Thai breadfruit's heartwood extract on melanogenesis-inhibitory and antioxidation activities. J Cosmet Sci. 2008;59:41-58. https://doi.org/10.1111/j.1468-2494.2008.00446_4.x PMid:18350234

30. Bonina F, Lanza M, Montenegro L, Puglisi C, Tomaino A, Trombetta $\mathrm{D}$, et al. Flavonoids as potential protective agents against photo-oxidative skin damage. Int J Pharm. 1996;145(1 2):87-94. https://doi.org/10.1016/s0378-5173(96)04728-x

31. Kale SS, Rajmane AH, Urunkar VC, Gaikwad MK, Bhandare SB. Formulation and in-vitro evaluation of sun protection factor of methanolic extract of Zanthoxylum rhetsa DC. Sunscreen lotion. Res J Pharmacogn Phytochem. 2011;3(5):206-10.

32. Amatullah L, Cahyaningrum TN, Fidyaningsih AN. Antioxidants effectivity in skin lotion formulation of mesocarp fruit extract lontar (Borassus Flabellifer) against white rats Wistar male in-situ. JPSCR J Pharm Sci Clin Res. 2017;2(1):25-34. https:// doi.org/10.20961/jpscr.v2i01.5236

33. Sharma G, Gadiya J, Dhanawat M. A Textbook of Cosmetic Formulations. Rajasthan: Mewar Univ Rajasthan; 2018. p. 901.

34. Akademi Farmasi Bina Husada Kendari. Formulasi Lotion dan Penentuan Nilai Sun Proctection Factor (SPF) Ekstrak Kulit Buah Naga Super Merah (Hylocereus costaricensis). Kendari: Akademi Farmasi Bina Husada Kendari; 2016. https://doi. org/10.30595/pharmacy.v15i1.2718

35. Wasitaatmadja SM. Penuntun ilmu kosmetik medik. Jakarta Penerbit Univ Indones. 1997;3:58-9.

36. Sayre RM, Agin PP, LeVee GJ, Marlowe E. A comparison of in vivo and in vitro testing of sunscreening formulas. Photochem Photobiol. 1979;29(3):559-66. https://doi.org/10.1111/j.1751-1097.1979.tb07090.x PMid:441130

37. Mansur JD, Mansur MC, Azulay RD. Determination of sun protection on factor by spectrophotometric methods. Bras Dermatol. 1986;61(3):121-4.

38. Tadros TF. Emulsion formation, stability, and rheology. Emuls Form Stab. 2013;1:1-75.

39. Purwaningsih S, Salamah E, Budiarti TA. Formulasi skin lotion dengan penambahan karagenan dan antioksidan alami dari rhizophora mucronata lamk. J Akuatika. 2014;5(1):55-62.

40. Caesar RY, Hapsari I, Dhiani BA. Formulasi dan aktivitas antibakteri lotion minyak atsiri buah adas (Foeniculum vulgare mill). Media Farm. 2015;11(1):41-54.

41. Harborne AJ. Phytochemical Methods a Guide to Modern Techniques of Plant Analysis. Berlin, Germany: Springer Science and Business Media; 1998.

42. Jagtap UB, Panaskar SN, Bapat VA. Evaluation of antioxidant capacity and phenol content in jackfruit (Artocarpus heterophyllus Lam.) fruit pulp. Plant foods Hum Nutr. 2010;65(2):99-104. https://doi.org/10.1007/s11130-010-0155-7 PMid:20198442

43. Wood C, Murphy E. Sunscreen Efficacy. Glob Cosmet Ind 2000;167(2):38-43

44. Wolf R, Morganti P, Ruocco V. Sunscreens. Clin Dermatol 1996;19(4):452-9. PMid:11535388

45. SNI. Sediaan Tabir Surya. Jakarta: SNI; 1996. p. 16.

46. Zulkarnain AK, Susanti M, Lathifa AN. The physical stability of lotion o/w and w/o from phaleria macrocarpa fruit extract as sunscreen and primary irritation test on rabbit. Maj Obat Tradis. 2013;18(3):141-50 